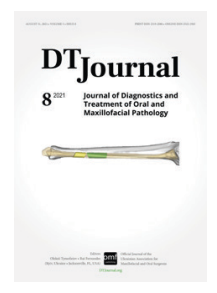

SECTION BUSINESS: LETTER

Ivan V. Nagorniak, MSc, PhD, Section Editor

\section{Opening New Markets for Your Private Practice Business and Manufacturing in Oral Surgery Needs}

\author{
Sebastien Camara \& Dmytro M. Zagorodnyi ${ }^{\mathrm{b}, *}$
}

A little competition is a good thing and severe competition is a blessing. Thank God for competition. - Jacob Kindleberger

Germany-borned United States mill owner

ral surgery and dentistry are highly competitive fields. Competition among private practices in Ukraine is intensifying. Moreover, according to the 2016 data, 3,734 private dental/stomatological clinics (offices) were registered in this country. ${ }^{1,2}$ And this despite the fact that the first private clinics in modern Ukraine start to appear only in 1991, the year of independence after the collapse of the Soviet Union. That is, we can assume that the market of private clinics for 25 years in Ukraine has grown by phenomenal 3,734 percent. At the same time, there is a tendency towards a decrease in the number of state stomatological policlinics what is also a part of the field`s evolution. ${ }^{1,2}$

\footnotetext{
a General Manager, U-impl Switzerland GmbH, Biel, Switzerland.

b,* Lawyer; General Manager, ID Solutions Law Company, Lead Auditor, Quality Management Systems ISO 9001, Kyiv, Ukraine.

idsolutionslawcompany@gmail.com (Dmytro Zagorodnyi)

Please cite this article as: Camara S, Zagorodnyi DM. Opening new markets for your private practice business and manufacturing in oral surgery needs. J Diagn Treat Oral Maxillofac Pathol 2021;5(8):87.
}

The interesting thing we should understand is that some of private clinics and their owners can compete not only in the treatment process, but also as manufacturers and sellers of the products for dentistry/oral surgery.

Previously, only a CE marking (CE abbreviation of Conformité Européenne [in French] mean European Conformity) and a dealer's office were required to operate in the $\mathrm{EU}$ market, but now, due to the reformatting of the legislation, it is necessary to have an authorized representative. Such companies' sectors as U-Represent ${ }^{3}$ can help Ukrainian manufacturers in uncomplicated and inexpensive way to reach European Union and Switzerland markets. The services of U-Represent are: 1) Pre-audit document review, 2) conformation of documents, 3) archive and storage location, 4) products registration in European database on medical devices (EUDAMED), 5) post-market surveillance monitoring, etc.

Thus, with authorized representatives, who are doctors with $\mathrm{PhD}$ and certified ISO (ie, the International Organization for Standardization) professionals, your dental business and manufacturing can hold a strong position not only on domestic market but also to take a share in the growing European and Switzerland marketplaces.

\section{REFERENCES}

1. Mazur IP, Pavlenko OV, Blyzniuk VG. The current state of dental care in Ukraine (in Ukrainian) [document on the internet]; October 20, 2017 [cited 2021 Aug 08]. Available from:

http://health-ua.com/article/31266-suchasnij-stanstomatologchno-dopomogi-v-ukran

2. Mazur IP, Pavlenko OV, Blyzniuk VG. The current state of dental care in Ukraine (in Ukrainian). Medical newspaper "Health of Ukraine of the XXI century" 2017;415(18):74-5.

3. U-represent: authorised representative for EU and Swiss markets [document on the internet]; June 01, 2021 [cited 2021 Aug 02]. Available from: https://u-represent.com/ 